\title{
PELAKSANAAN TUGAS DAN FUNGSI BURSA KERJA KHUSUS (BKK) DI SMK MUHAMMADIYAH 1 PLAYEN
}

\author{
Muhammad Dinata* \\ PT. Auto Mobil Prima, \\ *Corresponding Author: dinatamuhammad07@gmail.com
}

\begin{abstract}
This research aims to determine the duties and functions of Special Job Market (SJM) at SMK Muhammadiyah 1 Playen to work distribution of the graduates into the industry. This research is a descriptive quantitative to collect and analyze data. The subject of this research is the Special Employment Exchange administrators. Data collection techniques were used: (1) interviews; (2) questionnaire; (3) documentation. The results showed that: (1) The duties and functions in helping to channel graduates SJM SMK Muhammadiyah 1 Playen to the world of work (69.25\%), namely: (a) Providing employment information to students (80.00\%), (b) Conducting career guidance (58.75\%), (c) Liaise with the alumni (67.50\%), (d) hold employment activity (80.63\%), and (e) cooperation with government agencies and the private sector (59, 38\%); (2) Management SJM SMK Muhammadiyah 1 Playen in helping to channel graduates (78.88\%), namely: (a) Planning SJM (87.50\%), (b) Organizing SJM (80.00\%), (c) Implementation SJM (73.00\%), (d) Monitoring SJM (75.00\%); (3) The supporting factors SJM SMK Muhammadiyah 1 Playen in helping to channel graduates (73.70\%), namely: (a) Internal factors (75.83\%), (b) External factors (71.56\%).
\end{abstract}

Keywords: Special Job Market (SJM), duties, functions, graduates.

\begin{abstract}
Abstrak
Penelitian ini bertujuan untuk mengetahui pelaksanaan tugas dan fungsi Bursa Kerja Khusus (BKK) di SMK Muhammadiyah 1 Playen dalam menyalurkan lulusan ke dunia industri. Penelitian ini merupakan penelitian deskriptif kuantitatif untuk mengumpulkan dan menganalisa data. Subyek penelitian ini adalah pengurus Bursa Kerja Khusus. Teknik pengumpulan data yang digunakan adalah (1) wawancara; (2) angket; (3) dokumentasi. Teknik analisis data yang digunakan merupakan analisis deskriptif dimana berupa kata-kata kalimat yang dipisah menurut kategorinya. Hasil penelitian menunjukkan bahwa: (1) Tugas dan fungsi BKK dalam membantu menyalurkan lulusan SMK Muhammadiyah 1 Playen ke dunia kerja $(69,25 \%)$, yaitu : (a) Memberikan informasi ketenagakerjaan kepada siswa $(80,00 \%)$, (b) Mengadakan bimbingan karir $(58,75 \%)$, (c) Menjalin hubungan dengan alumni $(67,50 \%)$, (d) Mengadakan kegiatan ketenagakerjaan (80,63\%), dan (e) Menjalin kerjasama dengan Lembaga pemerintah dan swasta (59,38\%); (2) Manajemen BKK SMK Muhammadiyah 1 Playen dalam membantu menyalurkan lulusannya (78,88\%), yaitu: (a) Perencanaan BKK (87,50\%), (b) Pengorganisasian BKK (80,00\%), (c) Pelaksanaan BKK (73,00\%), (d) Pengawasan BKK (75,00\%); (3) Faktor pendukung BKK SMK Muhammadiyah 1 Playen dalam membantu menyalurkan lulusannya (73,70\%), yaitu: (a) Faktor Internal (75,83\%), (b) Faktor Eksternal (71,56\%). (4) Faktor Penghambat BKK SMK Muhammadiyah 1 Playen dalam membantu menyalurkan lulusannya (79,02\%), yaitu: (a) Faktor Internal (83,75\%), (b) Faktor Eksternal (74,29\%)..
\end{abstract}

Kata kunci: Bursa Kerja Khusus (BKK), tugas, fungsi, lulusan. 


\section{Muhammad Dinata, Zainal Arifin}

\section{PENDAHULUAN}

Dunia industri saat ini sedang menghadapi Revolusi Industri 4.0. Berdasarkan analisis Mckinsey Global Institute, Revolusi Industri 4.0 memberikan dampak yang sangat besar dan luas, terutama pada sektor lapangan kerja. Perkembangan yang begitu pesat perlu diimbangi pada sistem pendidikan yang sesuai dengan dunia industri. Tingkat keberhasilan pembangunan nasional pada suatu negara sangat dipengaruhi oleh sumber daya manusia sebagai modal aset untuk mengoptimalkan potensi sumber daya yang ada. Diharapkan manusia harus memiliki kompetensi yang mumpuni. Salah satu solusi untuk memenuhi tuntutan tersebut yaitu dengan pendidikan, salah satunya adalah pendidikan kejuruan yang bertujuan untuk menghasilkan lulusan yang terampil, kompetitif dan berkompetensi sesuai bidang keahlian (Tafakur \& Wakid, 2018). Pendidikan kejuruan merupakan bagian dari sistem Pendidikan yang mempersiapkan seseorang agar mampu bekerja pada satu kelompok bidang pekerjaan. Pendidikan kejuruan merupakan lembaga pendidikan yang menyiapkan peserta didik dalam mengusai salah satu bidang yang ada di dunia industri dalam waktu yang ditentukan oleh dinas terkait.

Dengan adanya SMK untuk memenuhi kebutuhan tenaga kerja yang kompeten atau dengan dengan kata lain SMK merupakan penghubung antara siswa dengan industri. Indikator keberhasilan SMK sebagai lembaga pendidikan yang menyiapkan tenaga kerja yaitu dengan banyaknya lulusan yang dapat diserap oleh dunia industri. Tahun demi tahun, peminat SMK sudah mulai meningkat. Berdasarkan data yang diperoleh melalui Badan Pusat Statistik (BPS) dalam Katalog Statistik SMK dan Katalog Statistik SMA edisi tahun 2017/2018, peminat SMK sebanyak 1.721.547 siswa dan peminat SMA sebanyak 1.613.979 siswa.

Indonesia sebagai negara berkembang tentunya masih banyak persoalan yang dimiliki, salah satunya yaitu tingkat pengangguran. Bulan Agustus 2018, tingkat pengangguran di Indonesia tergolong tertinggi untuk di negara ASEAN dengan angka 5.34\% atau 7 juta orang. Maka dengan memilih pendidikan SMK merupakan salah satu upaya untuk mengurangi tingkat pengangguran yang ada. Pemerintah Indonesia pun mendukung hal tersebut dengan mengeluarkan kebijakan berupa kebijakan porsi SMK 70\% dan SMA 30\%. Secara detail, hal itu telah dijelaskan dalam Instruksi Presiden No.9 tahun 2016 tentang Revitalisasi Sekolah Menengah Kejuruan Dalam Rangka Peningkatan Kualitas dan Daya Saing Sumber Daya Manusia Indonesia.

Secara umum lulusan SMK menyumbang jumlah pengangguran di Indonesia. Hal ini tidak sesuai dengan fungsi adanya SMK menjadi solusi permasalahan pengangguran. Menurut informasi dari BPS, dilihat dari tingkat pendidikan pada Agustus 2018, Tingkat Pengangguran Terbuka (TPT) 2018 untuk SMK masih mendominasi dibanding tingkat pendidikan lain, yaitu 
sebesar $11,24 \%$. Salah satu penyebab tidak efektifnya SMK dalam memenuhi tuntutan industri adalah kurang efektifnya suatu Bursa Kerja Khusus (BKK) yang dimiliki oleh SMK tersebut.

BKK sebagai lembaga yang ditugaskan mampu menyalurkan tenaga kerja dan juga memberikan bimbingan karir sehingga lulusan SMK pun merasa yakin dengan kemampuannya dan siap berkarier di dunia industri dengan modal keterampilan yang didapat selama menempuh di pendidikan kejuruan. Salah satunya, SMK Muhammadiyah 1 Playen memiliki BKK yang masih beroperasi hingga saat ini.

Berdasarkan hasil survei peneliti, bahwa BKK dalam memberikan layanan kepada lulusan SMK Muhammadiyah 1 Playen Kab. Gunungkidul pada tahun ajaran 2018/2019 yang terserap sebesar 47\%. Hal ini masih rendah dari yang seharusnya dapat mencapai $100 \%$. Kemudian, jumlah total lulusan yang mendaftar melalui Bursa Kerja Khusus adalah 164 siswa, sedangkan lulusan yang ada di SMK Muhammadiyah 1 Playen sebanyak 349 siswa. Berarti ada 185 siswa yang tidak mempergunakan BKK untuk mencari kerja. Hal ini menunjukkan bahwa jumlah lulusan yang mendaftar ke BKK untuk mencari kerja masih rendah. Dalam hal kerjasama dengan DU/DI memiliki 7 partner DU/DI di pulau Jawa untuk memasarkan lulusan. Hal tersebut masih belum optimal dalam memfasilitasi lulusannya ke DU/DI.

\section{METODE}

Jenis penelitian ini adalah penelitian deskriptif dengan pendekatan kuantitatif. Penelitian dilaksanakan pada bulan Oktober - November 2019 di SMK Muhammadiyah 1 Playen. Pada penelitian ini sumber data penelitian yang diambil adalah pengurus BKK di SMK Muh.1 Playen. Informan kunci (key informan) yang dipilih adalah ketua BKK SMK Muh.1 Playen. Pemilihan informan tersebut dengan alasan diduga mereka merupakan orang orang yang kompeten karena berhubungan langsung dengan objek penelitian sehingga mereka mengetahui dan dapat memberikan informasi tentang situasi dan kondisi BKK SMK Muh.1 Playen.

Instrumen yang digunakan dalam penelitian ini adalah menggunakan pedoman wawancara, pedoman dokumentasi, dan pedoman angket. Teknik pengumpulan data dilakukan dengan melakukan studi wawancara terhadap sumber data/informan tersebut di atas dan melakukan studi dokumentasi terhadap dokumen serta memberikan angket kepada pengurus BKK yang berkaitan dengan tugas dan fungsi Bursa Kerja Khusus SMK Muhammadiyah 1 Playen.

Teknik analisis data yang digunakan dalam penelitian ini adalah teknik analisis deskriptif. Data yang diperoleh setelah pengumpulan data yang berasal dari angket diringkas, 


\section{Muhammad Dinata, Zainal Arifin}

dipisahkan kategorinya sesuai rincian masalahnya, langkah ini disebut langkah skoring. Skala yang digunakan dalam penelitian ini adalah skala likert dengan menggunakan skala 1 sampai 4 (baik, cukup baik, kurang baik dan tidak baik). Setelah langkah skoring maka selanjutnya data dirubah kedalam bentuk yang lebih ringkas dan mudah dilihat, langkah ini disebut proses tabulasi. Dari tabulasi, analisis data dapat dilakukan dengan sederhana, yaitu dengan menggunakan prinsip analisis deskriptif, yaitu menggambarkan objek yang diteliti sesuai dengan apa adanya.

Sedangkan cara penyajian datanya menggunakan statistik deskriptif, yaitu statistik yang digunakan untuk menganalisis data dengan mendeskriptifkan atau menggambarkan data yang telah terkumpul sebagaimana adanya.

Selanjutnya untuk memberikan pemaknaan terhadap skor yang dicapai maka disusun pedoman penafsiran dengan langkah-langkah sebagai berikut:

1. Menghitung skor terendah yang mungkin dicapai. Dalam hal ini ada 4 jawaban yang disediakan sehingga setelah dijadikan persentase skor terndahnya adalah sebagai berikut: Skor terendah $=1 / 4 \quad$ x $100 \%=25 \%$

2. Menghitung skor tertinggi yang mungkin dicapai. Dalam hal ini ada 4 jawaban yang disediakan sehinggga setelah dijadikan persentase skor tertingginya sebagai berikut: Skor tertinggi $=4 / 4 \times 100 \%=100 \%$

3. Menghitung selisih skor tertinggi dan terendah (skor tertinggi dikurangi skor terendah) $100 \%-25 \%=75 \%$

4. Menentukan jumlah kategori yang akan digunakan untuk menafsirkan skor masing-masing pernyataan. Untuk variabel tugas BKK dan Manajemen BKK jumlah kategorinya ada 4, yaitu: 4 (baik), 3 (cukup baik), 2 (kurang baik), 1 (tidak baik). Sedangkan untuk variabel ketercapaian BKK, faktor pendukung dan faktor penghambat BKK jumlah kategorinya ada 4, yaitu: 4 (tinggi), 3 (cukup tinggi), 2 (cukup rendah), 1 (rendah).

5. Menentukan rentangan untuk masing-masing kategori. Caranya adalah menjumlah selisih skor tertinggi dengan skor terendah dibagi banyaknya kategori, atau diformulasikan sebagai berikut:

Rentangan $=($ Skor tertinggi-skor terendah $) /($ Banyaknya Kategori $)$

$$
\begin{aligned}
& =(100-25) / 4 \\
& =18,75 \%=19 \%
\end{aligned}
$$

6. Menetapkan skor masing-masing ketegori, dimana menurut hasil perhitungan di atas, banyaknya skor masing-masing adalah 19. Yaitu sebagai berikut:

Untuk Variabel tugas BKK dan manajemen BKK

$$
\text { Baik } \quad=82-100 \%
$$


Cukup Baik $=63-81 \%$

Kurang Baik $=44-62 \%$

Tidak Baik $=25-43 \%$

Untuk Variabel faktor pendukung dan faktor penghambat

$$
\begin{array}{ll}
\text { Tinggi } & =82-100 \% \\
\text { Cukup Tinggi } & =63-81 \% \\
\text { Cukup Rendah } & =44-62 \% \\
\text { Rendah } & =25-43 \%
\end{array}
$$

Langkah terakhir memberikan pemaknaan atau penafsiran terhadap skor masing-masing kriteria.

\section{HASIL DAN PEMBAHASAN}

\section{Aspek Tugas BKK}

Tabel 1. Persentase Aspek Tugas BKK

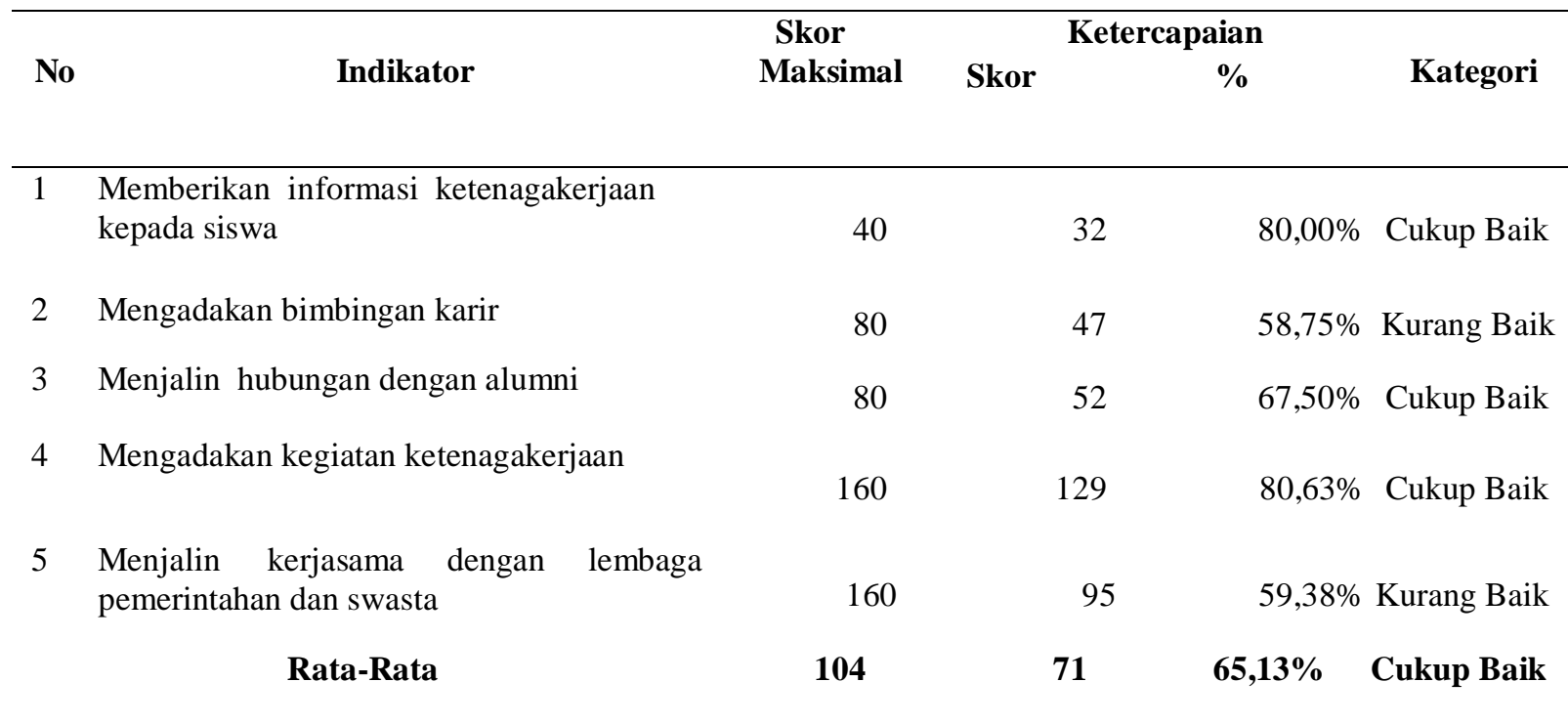

Tabel diatas menunjukan bahwa tugas dan fungsi BKK yang dijalankan BKK Muh.1 Playen berjalan dengan cukup baik (65,13\%). Pada lembar instrumen penelitian tugas BKK beberapa indikator seperti memberikan informasi ketenagakerjaan kepada siswa, menjalin hubungan dengan alumni, mengadakan kegiatan ketenagakerjaan, menjalin kerjasama dengan lembaga pemerintahan dan swasta berjalan dengan cukup baik. Sedangkan dalam hal bimbingan karir yang dilakukan BKK kurang baik.

BKK telah menjalankan dengan cukup baik $(80,00 \%)$ terkait penyebaran informasi kepada siswa jika ada lowongan pekerjaan yang diterima oleh pihak BKK dari dunia industri 
38 Muhammad Dinata, Zainal Arifin

BKK juga memiliki hubungan yang cukup baik $(67,50 \%)$ dengan beberapa pihak alumni yang berada di dunia industri/dunia kerja. BKK melakukan penelusuran terhadap lulusan yang telah bekerja maupun yang belum bekerja.

Dalam kegiatan yang berhubungan dengan ketenagakerjaan di lingkungan sekolah BKK telah menjalankan tugasnya dengan cukup baik (80,63\%). BKK dalam memberikan informasi dengan memanfaatkan sosial media, Whatsapp. BKK sering melakukan kegiatan pendaftaran lowongan pekerjaan jika ada permintaan tenaga kerja dan disertai dengan sosialisasi ketenagakerjaan. BKK juga sering mengadakan seleksi tenaga kerja bersama pihak industri di lingkungan sekolah.

BKK dalam menjalankan tugasnya membantu menyalurkan lulusan ke dunia industri juga didukung dengan cukup banyaknya pihak industri/dunia kerja yang menjadi mitra dalam penyaluran lulusan. Dunia industri juga beberapa kali mengirim instrukturnya untuk mengadakan pelatihan di SMK. Dalam hal penyaluran lulusan. BKK juga mencari informasi lowongan pekerjaan lewat internet dan membuat leaflet tenaga kerja ke dunia industri.

Terkait garis koordinasi dengan pihak pemerintah terkait dalam hal ini Depnakertrans/Dinsosnakertrans BKK juga telah menjalin komunikasi dan kerjasama yang baik. BKK selalu melaporkan kegiatanya ke pihak Depnakertrans/Dinsosnakertrans maupun terkait penyaluran lulusan ke dunia industri.

Namun dalam hal bimbingan karir terhadap lulusan/siswa yang siap bekerja tugas BKK berjalan dengan kurang baik $(58,75 \%)$. BKK kurang memiliki terobosan dalam hal mempersiapkan atau membimbing siswanya yang akan menuju dunia kerja. Hal ini terlihat karena BKK jarang mengadakan penyuluhan kerja serta uji coba seleksi tenaga kerja bagi siswa. Serta dalam indikator menjalin kerjasama dengan Lembaga pemerintah dan swasta berjalan dengan kurang baik (59,38\%). BKK kurang untuk memasarkan lulusan SMK ke dunia industri (57,50\%) sehingga industri tidak mengetahui kualitas lulusan dari SMK Muhammadiyah 1 Playen. Serta BKK SMK Muhammadiyah 1 Playen hingga saat ini belum pernah mengadakan pameran bursa kerja didalam sekolah (42,50\%). Diperlukannya perencanaan yang matang dari segi aturan, waktu, kurikulum, dana, dan sebagainya untuk menyelenggarakan job fair.

Pameran bursa kerja juga diperlukan oleh siswa atau alumni karena bisa mendapatkan informasi terkait lowongan kerja langsung dari perwakilan perusahannya masing-masing sehingga siswa ataupun alumni dapat memperoleh informasi lebih jelas. Hal ini juga termasuk dalam fungsi BKK yang tercantum dalam Peraturan Menteri Tenaga Kerja dan Transmigrasi RI No. 07/MEN/IV/2008 Pasal 20. Ada baiknya BKK benar-benar mengkoordinirkan rencana pelaksanaan kegiatan BKK dengan seluruh perangkat sekolah yang lain, karena hal ini tidak hanya berhubungan dengan BKK, namun juga unit yang lain. 
Kendala yang dihadapi BKK dalam penyebaran informasi ketenagakerjaan maupun pendataan siswa di website sekolah dan website BKK Direktorat PSMK yaitu karena kurangnya tenaga kerja yang dapat mengoperasikan IT dengan baik sehingga hal-hal tersebut belum dapat dilakukan secara maksimal. Berdasarkan hasil wawancara, narasumber mengatakan bahwa memang saat ini tenaga kerja yang menjadi bagian dari BKK dalam hal IT seperti mengurusi website sekolah belum ada, sehingga masih terkendala penginputan data Selain keterbatasan SDM yang ada, beban kerja yang berlebihan juga menjadi kendala yang dihadapi.

\section{Aspek Manajemen BKK}

Sebagaimana telah dipaparkan di atas bahwa manajemen adalah serangkaian kegiatan berupa merencanakan, mengorganisasikan, melaksanakan, mengawasi dengan segala upaya dalam mengatur dan mendayagunakan sumber daya manusia, sarana prasarana secara efisien dan efektif untuk mencapai tujuan organisasi yang telah ditetapkan. Dalam hal ini fungsi manajemen diterapkan dalam pengelolaan BKK di SMK Muhammadiyah 1 Playen.

Tabel 2. Persentase Aspek Manajemen BKK

\begin{tabular}{llcccc}
\hline No & Indikator & Skor & \multicolumn{2}{c}{ Ketercapaian } & Kategori \\
& & Maksimal & Skor & Persentase & \\
\hline 1 & Perencanaan BKK & 40 & 35 & $87,50 \%$ & Baik \\
2 & Pengorganisasian BKK & 200 & 170 & $80,00 \%$ & Cukup Baik \\
3 & Pelaksanaan BKK & 200 & 146 & $73,00 \%$ & Cukup Baik \\
4 & Pengawasan BKK & 80 & 60 & $75,00 \%$ & Cukup Baik \\
& Rata-Rata & $\mathbf{1 3 0}$ & $\mathbf{1 0 2 , 7 5}$ & $\mathbf{7 8 , 8 8 \%}$ & Cukup Baik
\end{tabular}

Hasil Penelitian deskriptif menunjukan bahwa variabel manajemen BKK yang dijalankan BKK SMK Muhammadiyah 1 Playen berjalan dengan cukup baik $(78,88 \%)$. Hal ini berarti BKK SMK Muhammadiyah 1 Playen telah menjalankan fungsi manajemen dalam membantu menyalurkan lulusan anak didiknya ke dunia industri secara optimal.

Pada lembar instrumen penelitian manajemen BKK beberapa indikator seperti perencanaan BKK berjalan dengan baik sedangkan indikator pelaksanaan, pengorganisasian dan pengawasan BKK berjalan dengan cukup baik.

Dalam pengelolaanya BKK mengadakan rapat kerja yang dihadiri oleh pengurus BKK untuk membahas masalah-masalah yang ditemui dalam kerja BKK dan jika ada perkembangan yang terjadi dalam dunia kerja. Di awal periode tahun ajar pendidikan BKK juga membuat program kerja dan membuat rencana-rencana/strategi yang akan dijalankan dalam satu periode kedepan. Dalam hal ini juga dimungkinkan BKK melakukan terobosan-terobosan terbaru jika diperlukan dalam pembuatan program kerja menyesuaikan kebutuhan yang ada di lapangan.

Dalam menjalankan roda kepengurusan BKK juga menjalin koordinasi yang baik dengan pihak-pihak terkait. BKK menjalin koordinasi yang baik dengan kepala sekolah dalam 
40 Muhammad Dinata, Zainal Arifin

menentukan program kerja yang akan dijalankan BKK, dalam menentukan langkahlangkah yang diperlukan dan dalam pengevaluasian kinerja BKK. Selain itu BKK juga menjalin koordinasi dan komunikasi yang baik dengan guru-guru di sekolah terutama dalam hal praktik Industri (PKL). Dalam lingkup pengurus BKK juga terjalin koordinasi yang baik karena sudah terdapat struktur organisasi yang dilengkapi dengan mekanisme kerja dan deskripsi kerja yang dapat dijalankan oleh pengurus BKK dengan baik.

Dalam menggerakan dan pelaksanaan dari perencanaan BKK berjalan dengan baik $(87,50 \%)$. BKK telah mengadakan kegiatan ketenagakerjaan di lingkungan sekolah yang sesuai dengan tugas BKK dan dilengkapi dengan sarana penunjang yang memadai seperti ruangan sekretariat yang baik dilengkapi dengan internet, perangkat telepon yang aktif, email yang aktif serta mading informasi BKK yang diupdate jika ada perkembangan terbaru.

Diakhir periode tahun ajaran pendidikan BKK juga mengadakan rapat evaluasi terhadap kegiatan-kegiatan yang terjadi selama setahun terakhir. Hasil dari evaluasi juga dibukukan dan dibahas dengan kepala sekolah dalam rapat pengurus sekolah. Hasil dari evaluasi tersebut akan dijadikan sebagai acuan dan pandangan bagi langkah-langkah dan apa yang akan dijalankan oleh BKK dalam satu tahun kedepan.

Namun dalam hal mengadakan pendataan instansi/perusahaan pengguna tenaga kerja lulusan dengan kategori kurang baik $(57,50 \%)$. BKK belum memiliki data instansi pengguna tenaga kerja lulusan sehingga BKK sulit dalam melakukan pemasaran kembali ke instansi yang memiliki tenaga kerja berasal dari lulusan SMK Muh. 1 Playen. Padahal hal tersebut akan meningkatkan kepercayaan industri terhadap kualitas lulusan yang disalurkan oleh BKK SMK Muh. 1 Playen.

\section{Aspek Faktor Pendukung BKK}

Tabel 3. Persentase Aspek Faktor Pendukung BKK

\begin{tabular}{cccccl}
\hline No & Indikator & Skor & \multicolumn{2}{c}{ Ketercapaian } & \\
& & Maksimal & Skor & $\%$ & Kategori \\
\hline 1 & Faktor Internal & 120 & 91 & $75,83 \%$ & Cukup Tinggi \\
2 & Faktor Eksternal & 320 & 229 & $71,56 \%$ & Cukup Tinggi \\
\multicolumn{2}{l}{ Rata-Rata } & $\mathbf{2 2 0}$ & $\mathbf{1 6 0}$ & $\mathbf{7 3 , 7 0 \%}$ & Cukup Tinggi \\
\hline
\end{tabular}

Hasil Penelitian deskriptif menunjukan bahwa variabel faktor pendukung BKK SMK Muhammadiyah 1 Playen cukup tinggi. Hal ini berarti BKK SMK Muhammadiyah 1 Playen telah mendapatkan dukungan yang cukup baik dari berbagai pihak terkait dalam menjalankan tugas dan peranya sebagai penyalur lulusan ke dunia industri.

Dalam lingkup internal BKK mendapatkan dukungan yang cukup tinggi $(75,83 \%)$ dari kepala sekolah dan juga didukung dengan baiknya koordinasi dari pengurus-pengurus BKK 
dalam menjalankan tugasnya masing-masing. Pengurus BKK dapat menjalankan deskripsi dan mekanisme kerja masing-masing yang menunjang lancarnya pengelolaan dalam lingkup BKK.

Sedangkan dalam lingkup eksternal BKK mendapatkan dukungan yang cukup tinggi $(71,56 \%)$ dalam menjalankan tugas dan kerjanya. Dari pihak guru-guru maupun karyawan sekolah selain pengurus BKK juga aktif membantu kerja BKK dalam menyampaikan informasi ketenagakerjaan kepada siswa-siswi. Dari pihak alumni yang berada di dunia industri juga mendukung kerja dari BKK dengan membantu menyampaikan informasi ketenagakerjaan terbaru kepada pihak BKK. Industri terkait juga aktif menyampaiakn informasi lowongan pekerjaan sehingga pihak BKK hampir tidak pernah kesulitan dalam menyalurkan lulusannya ke dunia industri. Hal ini juga dilengkapi dengan kualifikasi kerja yang dibutuhkan beserta penempatan kerjanya. Selain itu pihak industri juga telah mengakui kualitas lulusan SMK Muhammadiyah 1 Playen sehingga tidak ada keraguan dari pihak industri dalam mencari tenaga kerja dari lingkungan SMK Muhammadiyah 1 Playen. Dari dinas terkait seperti Depnakertrans/ dinsosnakertrans juga mendukung kerja dari BKK dengan memberikan bimbingan dan mengevaluasi jalanya penyaluran tenaga kerja di SMK Muhammadiyah 1 Playen.

\section{Aspek Faktor Penghambat BKK}

Tabel 4. Persentase Aspek Faktor Penghambat BKK

\begin{tabular}{clcccl}
\hline No & Indikator & $\begin{array}{c}\text { Skor } \\
\text { Maksimal }\end{array}$ & & Ketercapaian & \multicolumn{1}{c}{ Kategori } \\
& & 80 & Skor & Persentase & \\
\hline 1 & Faktor Internal & 280 & 67 & $83,75 \%$ & Tinggi \\
2 & Faktor Eksternal & 208 & $74,29 \%$ & Cukup Tinggi \\
Rata-Rata & $\mathbf{1 8 0}$ & $\mathbf{1 3 7 . 5}$ & $\mathbf{7 9 , 0 2 \%}$ & $\begin{array}{l}\text { Cukup Tinggi } \\
\text { Tinggi }\end{array}$ \\
\hline
\end{tabular}

Hasil Penelitian deskriptif menunjukan bahwa variabel faktor penghambat BKK SMK Muhammadiyah 1 Playen cukup tinggi. Hal ini menunjukan BKK SMK Muhammadiyah 1 Playen Sleman hampir sering menemui hambatan dalam menjalankan tugasnya.

Dalam lingkup internal BKK hampir sering menemui hambatan- hambatan yang berarti karena dari pengurus BKK belum maksimal dalam menjalankan deskripsi dan mekanisme kerja dengan baik.

Sedangkan dalam lingkup eksternal BKK mendapatkan hambatan yang tinggi, hal ini menunjukan pihak BKK hampir sering menemui hambatan dalam menjalankan kerjanya dari pihak eksternal. Dalam mekanisme kerjanya untuk menyalurkan informasi kepada lulusan belum berjalan baik karena BKK sulit mengabari jika memiliki informasi lowongan kerja 


\section{Muhammad Dinata, Zainal Arifin}

dikarenakan minimnya data alumni yang dimiliki hanya pada kertas angket yang dapat hilang atau kondisi angket yang sudah lama.

Selain itu, BKK SMK Muhammadiyah 1 Playen sulit mendapatkan informasi terkait job fair yang diadakan oleh perguruan tinggi. Hal tersebut semestinya dapat menunjang BKK dalam memberikan tambahan informasi pekerjaan kepada alumni melalui job fair yang diadakan oleh perguruan tinggi.

Wawancara yang dilakukan oleh peneliti dan narasumber selaku Ketua BKK diperoleh bahwa saat ini seleksi lowongan pekerjaan disekolah tidak sebanyak dengan tahun-tahun sebelumnya dikarenakan pihak industri dibatasin untuk merekrut tenaga kerja diluar daerah domisili industri oleh pemerintah daerah. Hal tersebut juga mengurangi jumlah lulusan yang mendapatkan informasi lowongan kerja melalui BKK.

Pada akhirnya dapat dinyatakan bahwa tugas dan fungsi Bursa Kerja Khusus di SMK Muhammadiyah 1 Playen memiliki peranan penting dalam memasarkan tamatan salah satunya yaitu penelusuran lulusan. Secara administratif, BKK memang mengalami kendala dalam pendataan alumni dikarenakan hal tersebut telah diterapkan pada bidang humas SMK Muhammadiyah 1 Playen dan tidak ada koordinasi dengan pihak BKK.

Penelusuran tamatan sangat perlu dioptimalkan karena hal ini termasuk dalam penilaian kelembagaan SMK sebgaimana yang diatur dalam Depdikbud. Alumni merupakan asset bagi SMK, karena dengan berhasilnya melakukan penelusuran tamatan beberapa manfaat dapat didapatkan.

Hal ini juga senada dengan yang disampaikan oleh Pambayun (2014) dalam penelitiannya. Manfaat yang dapat diambil diantarannya yaitu alumni merupakan sarana promosi SMK ke tempat kerjanya, sebagai salah satu informasi lowongan pekerjaan, alumni yang sukses dapat membantu alumni lain dari almamaternya dan membantu dalam pelaksanaan bimbingan karir di SMK.

Hal ini juga senada dengan yang disampaikan oleh Triantini (2018) dalam penelitiannya, kendala yang dimiliki BKK yaitu kurangnya pengurus BKK, kurangnya pemanfaatan IT serta pengelolaan administrasi yang terkendala pada SDM.

Penelitian yang dilakukan oleh Witono (2012) dengan judul "Pengelolaan Bursa Kerja Khusus Di SMK Negeri 2 Klaten Tahun Ajaran 2010/2011” yang diantaranya menemukan adanya hambatan yaitu persaingan dengan BKK sekolah lain sehingga menghambat BKK dalam melaksanakan tugas dan fungsinya.

Temuan ini sekaligus mendukung penelitian dari Bahar (2015) dengan judul "Evaluasi tugas dan fungsi Bursa Kerja Khusus Dalam Membantu Menyalurkan Lulusan Ke Industri Di SMK Negeri 2 Depok" yang diantaranya mendapatkan hasil (1) BKK telah menjalankan tugas 
dalam membantu menyalurkan lulusan cukup baik $(68,21)$; (2) Manajemen BKK telah dikelola cukup baik $(79,62)$ dengan faktor pendukung yang ditemukan yaitu dukungan dari pihak sekolah, Disnakertrans, fasilitas yang memadai, alumni dan dunia industri aktif bekerjasama dengan BKK sehingga BKK dapat mencapai tujuannya dalam menyalurkan lulusan SMK dengan maksimal

\section{SIMPULAN}

Berdasarkan hasil penelitian dan pembahasan mengenai peran BKK dalam penyaluran lulusan siswa SMK Muhammadiyah 1 Playen dapat ditarik kesimpulan yaitu sebagai berikut.

1. Tugas dan fungsi BKK dalam membantu menyalurkan lulusan SMK Muhammadiyah 1 Playen ke dunia kerja (69,25\%), yaitu : (a) Memberikan informasi ketenagakerjaan kepada siswa (80,00\%), (b) Mengadakan bimbingan karir (58,75\%), (c) Menjalin hubungan dengan alumni (67,50\%), (d) Mengadakan kegiatan ketenagakerjaan (80,63\%), dan (e) Menjalin kerjasama dengan Lembaga pemerintah dan swasta $(59,38 \%)$.

2. Manajemen BKK SMK Muhammadiyah 1 Playen dalam membantu menyalurkan lulusannya (78,88\%), yaitu: (a) Perencanaan BKK (87,50\%), (b) Pengorganisasian BKK (80,00\%), (c) Pelaksanaan BKK (73,00\%), (d) Pengawasan BKK (75,00\%).

3. Faktor pendukung BKK SMK Muhammadiyah 1 Playen dalam membantu menyalurkan lulusannya (73,70\%), yaitu: (a) Faktor Internal (75,83\%), (b) Faktor Eksternal (71,56\%).

4. Faktor Penghambat BKK SMK Muhammadiyah 1 Playen dalam membantu menyalurkan lulusannya (79,02\%), yaitu: (a) Faktor Internal (83,75\%), (b) Faktor Eksternal (74,29\%).

Berdasarkan hasil penelitian dan pembahasan, saran dari peneliti yaitu sebagai berikut:

1. Pengurus BKK perlu menetapkan jadwal untuk pertemuan khusus yang telah disepakati bersama oleh seluruh pengurus BKK untuk meningkatkan koordinasi tugas masing-masing pengurus, sehingga tugas tidak hanya terfokus pada beberapa orang saja.

2. Pengurus BKK perlu menentukan program kerja sesuai dengan kebutuhan dan keputusan seluruh pengurus BKK sehingga mampu melaksanakan program kerja tersebut dengan semaksimal mungkin tanpa kekurangan apapun.

3. Pengurus BKK perlu membuatan angket penelusuran alumni dengan google form untuk menjadi arsip pendataan alumni yang efisien dan efektif ketimbang menggunakan kertas angket yang dapat terurai jika disimpan dalam waktu yang lama.

4. Pengurus BKK mengajukan kepada kepala sekolah untuk mengeluarkan peraturan sekolah terkait kewajiban bagi alumni untuk mengisi angket penelusuran alumni sebelum 
44 Muhammad Dinata, Zainal Arifin

mengambil ijazah agar seluruh alumni terdata secara menyeluruh dan tidak ada yang tertinggal satupun.

5. BKK dapat memaksimalkan media yang ada untuk penyebaran informasi mengenai ketenagakerjaan. Diperlukannya pengurus yang mampu memaksimalkan perkembangan teknologi saat ini dengan merekrut alumni yang berpotensi untuk membantu tugas tersebut.

6. BKK dapat mempertimbangkan untuk mengadakan job fair di lingkungan sekolah serta mengadakan bimbingan karir untuk siswa dan alumni. Namun hal tersebut perlu didiskusikan dengan bidang lain yang ada disekolah agar kegiatan tersebut tidak terbentur dengan acara lainnya serta mendiskusikan seberapa efektif kegiatan tersebut serta berkomunikasi dengan pihak industri terkait dukungan mereka dalam kegiatan tersebut.

7. Pengelolaan administratif sangat perlu ditingkatkan, baik untuk data penelusuran lulusan, jumlah DU/DI yang sudah bekerjasama, serta dokumen-dokumen penting lainnya.

8. Pihak BKK lebih aktif dalam membuat kebijakan-kebijakan atau terobosan-terobosan terbaru sesuai perkembangan yang ada, sehingga jalanya BKK tidak stagnan dan ada inovasi didalamnya.

\section{DAFTAR PUSTAKA}

Arikunto, S. \& Yuliana, L. (2008). Manajemen Pendidikan. Yogyakarta: Aditya Media \& FIP UNY.

Bahar, Z.A. (2015). Efektivitas Manajemen Bursa Kerja Khusus (BKK) Dalam Membantu Menyalurkan Lulusan ke Industri di SMK N 2 Depok. Skripsi. Yogyakarta: FT Universitas Negeri Yogyakarta.

Depdikbud. (2003). Undang-Undang RI Nomor 20 Tahun 2003 tentang Sistem Pendidikan Nasional.

Hermansyah, dkk. (2009). Manajemen Bursa Kerja Khusus (BKK) SMK. Yogyakarta: Paramitra Publishing.

Nurhadi, D., \& Lyau, N.-M. (2018). Cultivating Responsibilities of Vocational Teachers: A Framework for Preparing Education to Work. Jurnal Pendidikan Teknologi Dan Kejuruan, 24(2), 295-302. http,s://doi.org/10.21831/JPTK.V24I2.19347.

Pambayun, N.A.Y. (2014). Kinerja Bursa Kerja Khusus (BKK) SMK Negeri Bidang Keahlian Teknologi dan Rekayasa di Kabupaten Sleman. Jurnal Pendidikan Vokasi, Vol. 4, No. 2, $246-261$.

Peraturan Pemerintah Republik Indonesia Nomor 74 Tahun 2008 tentang Guru.

Sugiyono. (2013). Metode Penelitian Manajemen. Bandung: Alfabeta. 
Sriati. (2012). Peran Bursa kerja Khusus Dalam Upaya Peningkatan Kompetensi Siswa SMK N 1 Ngawi. Skripsi. Surakarta: FKIP Universitas Sebelas Maret.

Triantini, D. (2019). Evaluasi Peran Bursa Kerja Khusus Dalam Penyaluran Lulusan Siswa SMK Negeri 2 Yogyakarta di Dunia Kerja. Skripsi. Yogyakarta: FT Universitas Negeri Yogyakarta.

Wakid, M., \& Tafakur, T. (2018). PROFIL KOMPETENSI PRODUKTIF SISWA SMK TKR DALAM RANGKA SERTIFIKASI KEAHLIAN UNTUK PERSAINGAN GLOBAL. Jurnal Pendidikan Vokasi Otomotif, 1(1), 77-88.

Witono, A. (2012). Pengelolaan Bursa Kerja Khusus Di Sekolah Menengah Kejuruan (SMK). Skripsi. Surakarta: FKIP Universitas Sebelas Maret. 
46 Muhammad Dinata, Zainal Arifin 